Bài báo khoa học

\title{
Đánh giá khả năng áp dụng giải pháp thoát nước đô thị bền vững tại khu vực đang đô thị hóa ở huyện Bình Chánh, thành phố Hồ Chí Minh
}

\author{
Nguyễn Thị Mai Lan ${ }^{1}$, Trần Đức Dũng ${ }^{*}$, Châu Nguyễn Xuân Quang², Ngô Ngọc Hoàng \\ Giang $^{2}$, Hồ Văn Hòa ${ }^{2}$, Lưu Văn Tấn ${ }^{3}$ \\ ${ }^{1}$ Trung tâm Quản lý Nước và Biến đổi khí hậu, Viện Môi Trường và Tài Nguyên, Đại học \\ Quốc Gia TPHCM; mailan300496@gmail.com; dungtranducvn@yahoo.com \\ ${ }^{2}$ Phòng Thủy văn và Tài Nguyên Nước, Viện Môi Trường và Tài Nguyên, Đại học Quốc \\ Gia TPHCM (HYDROWARE-IRE-VNU); cnxquang@gmail.com; \\ nnhgiang.env@gmail.com; harryhoa@gmail.com \\ ${ }^{3}$ Trung tâm Quản lý Hạ tầng kỹ thuật TPHCM; taanslv@yahoo.com \\ *Tác giả liên hệ: dungtranducvn@yahoo.com; Tel.:+84-902007905
}

Ban Biên tập nhận bài: 12/8/2021; Ngày phản biện xong: 27/9/2021; Ngày đăng bài: $25 / 12 / 2021$

Tóm tắt: Quá trình đô thị hóa và tác động của biến đổi khí hậu là một trong những nguyên nhân gây ra tình trạng ngập lụt cục bộ. Nghiên cứu này nhằm đánh giá khả năng áp dụng giải pháp thoát nước đô thị bền vững (SUDS) ở khu vực đang đô thị hóa, huyện Bình Chánh. Nghiên cứu sử dụng mô hình EPA-SWMM để mô phỏng 2 kịch bản áp dụng SUDS: KB1 (Tăng khả năng lưu trữ tạm thời để tái sử dụng nước mưa) và KB2 (Làm giảm lưu lượng đỉnh của dòng chảy), xây dựng bộ tiêu chí kết hợp với khảo sát 30 hộ dân, 10 chuyên gia và chính quyền địa phương để đánh giá khả năng áp dụng SUDS. Kết quả mô phỏng kịch bản đã mang lại hiệu quả giảm ngập đáng kể: $\mathrm{KB} 1$ với thời gian ngập giảm $2,68 \%$ và tổng lượng ngập giảm $0,52 \%$; KB2 với thời gian ngập giảm $22,85 \%$ và tổng lượng ngập giảm $17,24 \%$. Dựa trên mức độ phù hợp với bộ tiêu chí và kết quả khảo sát các bên liên quan cho thấy, vỉa hè thấm và vườn mưa được đánh giá phù hợp với khu vực nghiên cứu nhất, tiếp theo là hệ thống thu nước mưa và cuối cùng là mái nhà xanh. Nghiên cứu kết luận SUDS giúp giảm ngập đáng kể và nên được áp dụng để góp phần hỗ trợ công tác quản lý rủi ro ngập lụt đô thị hiệu quả hơn.

Từ khóa: Đang đô thị hóa; Huyện Bình Chánh; EPA-SWMM; SUDS.

\section{Mở đầu}

Trong những thập kỷ gần đây, huyện Bình Chánh thường xuyên bị ảnh hưởng bởi ngập lụt cục bộ. Nguyên nhân là do quá trình đô thị hóa đã làm mất đi các vùng trũng chứa nước tự nhiên, thu hẹp thảm phủ thấm nước và thay vào đó là các bề mặt không thấm nước. Trong bối cảnh biến đổi khí hậu $(\mathrm{BĐKH})$ làm cường độ mưa ngày càng cao, gia tăng lưu lượng đỉnh lũ làm cho hệ thống thoát nước không kịp tải lưu lượng nước mưa [1-2], gây ngập úng ảnh hưởng đến cuộc sống của người dân và sự phát triển kinh tế xã hội [3]. Trong những năm qua việc quản lý ngập lụt đô thị đã đưa ra nhiều giải pháp chống ngập ở khu vực đang đô thị hóa bằng các phương án công trình như đê và hồ chứa nước ngầm để giảm thiểu tình trạng ngập lụt vẫn còn gặp nhiều khó khăn và rủi ro [4]. Vì vậy, hệ thống thoát nước đô thị cần được nghiên cứu để đề ra các giải pháp phát triển theo hướng bền vững.

Tạp chí Khí tuợng Thủy văn 2021, 732, 49-64; doi:10.36335/VNJHM.2021(732).49-64 http://tapchikttv.vn/ 
Công nghệ Hệ thống thoát nước đô thị bền vững SUDS (Sustainable Urban Drainage Systems) được lựa chọn nhằm đảm bảo tính bền vững về mặt kinh tế, xã hội và môi trường. 04 giải pháp SUDS được triển khai thành công ở nhiều nơi trên thế giới được xem xét nhu: (i) Mái nhà xanh (Green Roofs) giúp tăng khả năng ngăn chặn, tích trữ nước mưa, bốc hơi và thoát hơi nước, đồng thời hoạt động tốt trong các đợt bão nhỏ [5-6], những thành phần trong mái nhà xanh giúp hạ nhiệt độ không khí đô thị và chống lại hiệu ứng đảo nhiệt [7]; (ii) Thu nước mưa (Rainwater Harvesting) có thể là nguồn bổ sung cho các nguồn cung cấp nước, giảm xả thải trực tiếp vào hệ thống thoát nước và chống ngập lụt đô thị, nhằm mục đích là thu gom và tái sử dụng nước mưa để đảm bảo cho việc tưới tiêu cho các mái nhà xanh [8]; (iii) Vườn mưa (rain gardens) là một giải pháp kết hợp giữa việc tạo cảnh quan và xử lý nước mưa trong môi trường đô thị, đây là giải pháp sinh thái giúp cải thiện chất lượng nước mưa, loại bỏ các chất ô nhiễm, giảm lượng dòng chảy và tạo điều kiện xâm nhập của nước sạch, góp phần cải tạo môi trường đất [9]; (iv) Vỉa hè thấm (Porous Pavements) là một công nghệ vừa tăng cường thấm vừa cải thiện chất lượng dòng chảy bể mặt, mặt đường thấm là một thiết bị thấm thay thế, trong đó dòng chảy bề mặt được chuyển hướng qua bề mặt thấm vào một vỉa đá nằm dưới cùng bề mặt [10], mặt đường thấm thường hoạt động để kiểm soát khối lượng dòng chảy, kiểm soát ô nhiễm lan tỏa, và khi chúng xâm nhập vào nước trong đất, chúng thúc đẩy quá trình nạp lại nước ngầm [11].

Mô hình quản lý nước mưa SWMM (Storm Water Management Model) được xây dựng ở hai trường đại học San Phansico và Florida (Mỹ) do cơ quan bảo vệ môi trường Hoa Kỳ (EPA). Mô hình SWMM ra đời vào năm 1971 và đã trải qua nhiều lần nâng cấp. Mô hình được sử dụng rộng rãi trên thế giới với các công tác quy hoạch, phân tích và thiết kế các hệ thống thoát nước mưa, hệ thống thoát nước chung, hệ thống thoát nước thải và những hệ thống tiêu khác trong vùng đô thị cũng như những vùng không phải đô thị [12]. Trong nghiên cứu này, mô hình EPA-SWMM Ver 5.0 được sử dụng để mô phỏng hiện trạng ngập lụt đô thị và sử dụng công nghệ Phát triển Tác động thấp LID để đánh giá khả năng áp dụng SUDS nhằm giảm thiểu ngập lụt đô thị tại khu vực nghiên cứu. Trên thế giới, mô hinh SWMM đã được nghiên cứu và sử dụng từ lâu: Nghiên cứu sử dụng mô hình SWMM để đánh giá tác động của LID trong khu vực đô thị [13]; Nghiên cứu ứng dụng mô hình SWMM đánh giá hiệu quả của giải pháp vườn mưa tại Nhật Bản [9]; Các nghiên cứu dùng để đánh giá vấn đề về BĐKH ảnh hưởng đến cơ sở hạ tầng đô thị bị xuống cấp ở nhiều khu vực [14]. Một số kết quả nghiên cứu SWMM ở Việt Nam có thể kể đến là: Nghiên cứu mô phỏng thoát nước đô thị ở Huế trong trận mưa tháng 10 năm 2019 [15]; Nghiên cứu ứng dụng mô hình SWMM để đánh giá tính khả thi của SUDS tại lưu vực kênh Nhiêu Lộc-Thị Nghè, TP.HCM [16]; Nghiên cứu mô phỏng mức độ ngập và đề xuất giải pháp chống ngập cho khu vực Văn Thánh, TP.HCM [17]; Mô hình SWMM còn ứng dụng trong phân tích mạng lưới thoát nước khu đô thị mới ở Lê Minh Xuân, huyện Bình Chánh, TP.HCM [18].

Để giải quyết vấn đề ngập lụt đô thị trong bối cảnh ngày càng tăng do tác động của BĐKH, việc ứng dụng giải pháp SUDS để quản lý ngập lụt đô thị bền vững hơn cho khu vực đang đô thị hóa ở huyện Bình Chánh là rất cấp thiết. Mặc dù SUDS đã được triển khai thành công ở nhiều nơi trên thế giới nhưng nó vẫn tồn tại nhiều rủi ro tiềm tàng về kỹ thuật, môi trường, kinh tế-xã hội nếu không được thử nghiệm về sự phù hợp của nó với điều kiện địa phương, nên cần được đánh giá tính khả thi trước khi áp dụng. Vì vậy, nghiên cứu sử dụng mô hình EPA-SWMM để mô phỏng khả năng áp dụng giải pháp SUDS kết hợp với phương pháp điều tra xã hội học, nhằm thu thập ý kiến của các bên liên quan giúp mang lại nhiều lợi ích, giá trị kinh tế, xã hội, và thân thiện với môi trường cho cộng đồng dân cư. Mục đích của nghiên cứu: (1) Đánh giá được hiện trạng hệ thống thoát nước, hiện trạng sử đất và ngập lụt tại khu vực đang đô thị hóa huyện Bình Chánh; (2) Lựa chọn được giải pháp SUDS phù hợp với điều kiện thực tế tại địa phương; (3) Xác định được tiềm năng-thách thức về khả năng áp dụng giải pháp SUDS lồng ghép hạ tầng hiện hữu và đề xuất giải pháp khắc phục những hạn chế khi áp dụng SUDS tại địa phương. 


\section{Phương pháp nghiên cứu}

\subsection{So đồ cấu trúc nghiên cưu}

Để đánh giá khả năng áp dụng SUDS cho khu vực đang đô thị hóa ở huyện Bình Chánh, nghiên cứu sử dụng phương pháp tiếp cận là mô hình hóa kết hợp với điều tra xã hội học và xây dựng bộ tiêu chí. Mô hình được sử dụng trong nghiên cứu này là mô hình EPA-SWMM dùng để mô phỏng và đánh giá hiệu quả áp dụng SUDS. Phương pháp điều tra xã hội học nhằm thu thập ý kiến của chuyên gia, chính quyền và người dân địa phương nhằm phục vụ cho công tác xây dựng bộ tiêu chí, đánh giá tiềm năng và thách thức khi áp dụng SUDS. So đồ thực hiện các nội dung nghiên cứu được trình bày như Hình 1.

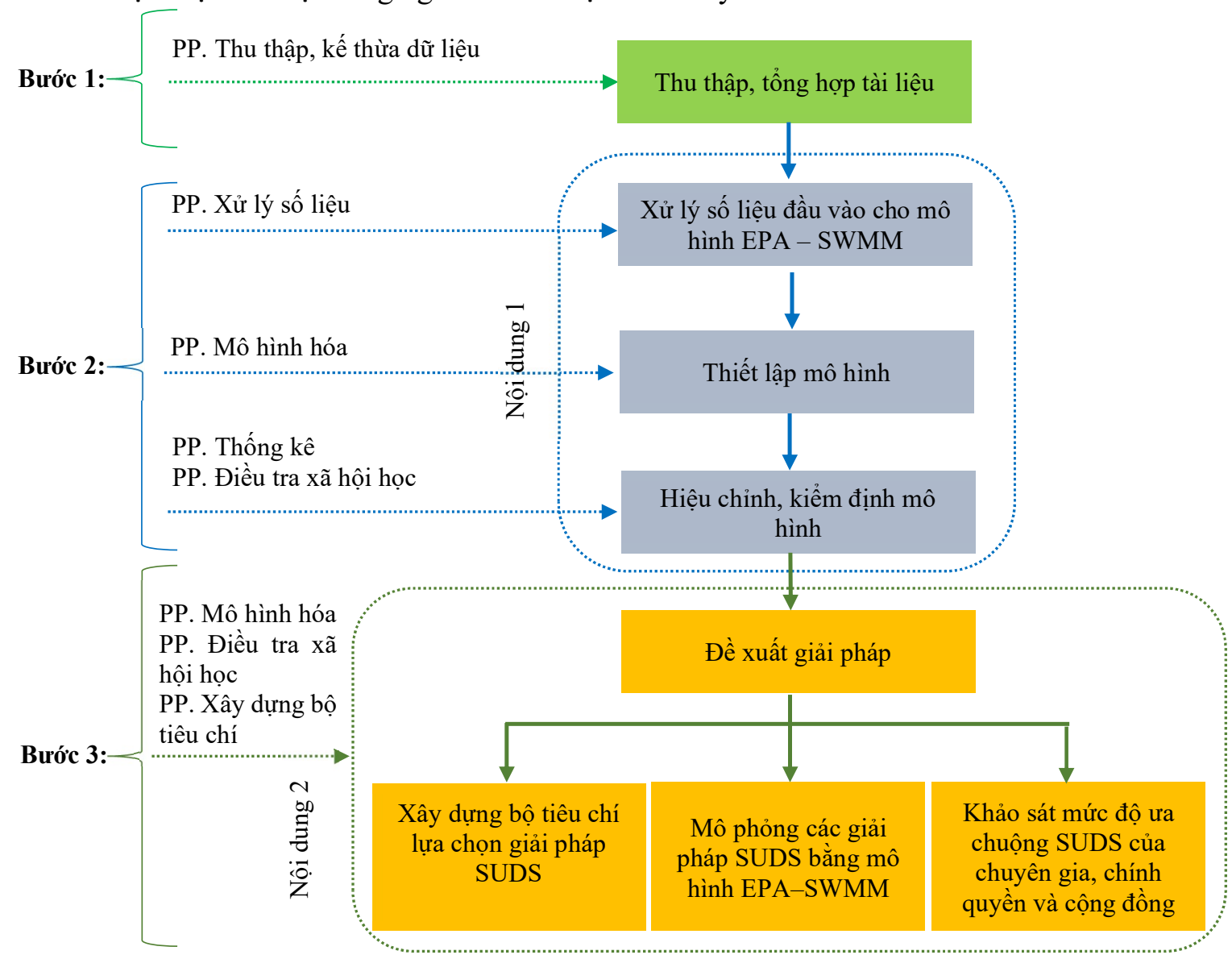

Hình 1. Quy trình thực hiện nghiên cứu.

\subsection{Khu vục nghiên cứu}

Huyện Bình Chánh nằm ở phía Tây-Tây Nam của Thành phố Hồ Chí Minh. Tọa độ địa lý của huyện là $106^{\circ} 27^{\prime} 51^{\prime \prime}-106^{\circ} 42^{\prime}$ kinh Đông và $102^{\circ} 27^{\prime} 38^{\prime \prime}-10^{\circ} 52^{\prime} 30^{\prime \prime}$ vĩ Bắc. Huyện Bình Chánh là một trong 5 huyện ngoại thành, có tổng diện tích tự nhiên 25.255 ha, chiếm $12,05 \%$ diện tích toàn Thành phố. Tổng dân số toàn Huyện tính tới cuối năm 2020 là 730.477 người, với 15 xã và 01 thị trấn, xã có diện tích lớn nhất là xã Lê Minh Xuân với diện tích 3.509 ha, xã nhỏ nhất là xã An Phú Tây với diện tích 586,58 ha.

Huyện Bình Chánh có hệ thống sông, kênh, rạch khá đa dạng với 86 tuyến có chức năng tiêu thoát nước với tổng chiều dài $111,750 \mathrm{~km}$ và 79 tuyến có chức năng tưới tiêu phục vụ sản xuất nông nghiệp, nuôi trồng thủy sản, phát triển rừng với tổng chiều dài $123,504 \mathrm{~km}$. Phần lớn sông, rạch của huyện Bình Chánh nằm ở khu vực hạ lưu, nên nguồn nước bị ô nhiễm do nước thải từ các khu công nghiệp của thành phố đổ về: Nước đen từ kênh Tàu Hủ, kênh 
Tân Hóa-Lò Gốm, kênh Đôi, rạch Nước Lên, rạch Cần Giuộc,... đã ngày càng gây ảnh hưởng lớn đến sản xuất nông nghiệp (đặc biệt là nuôi trồng thủy sản) cũng như đối với môi trường sống của nhân dân.

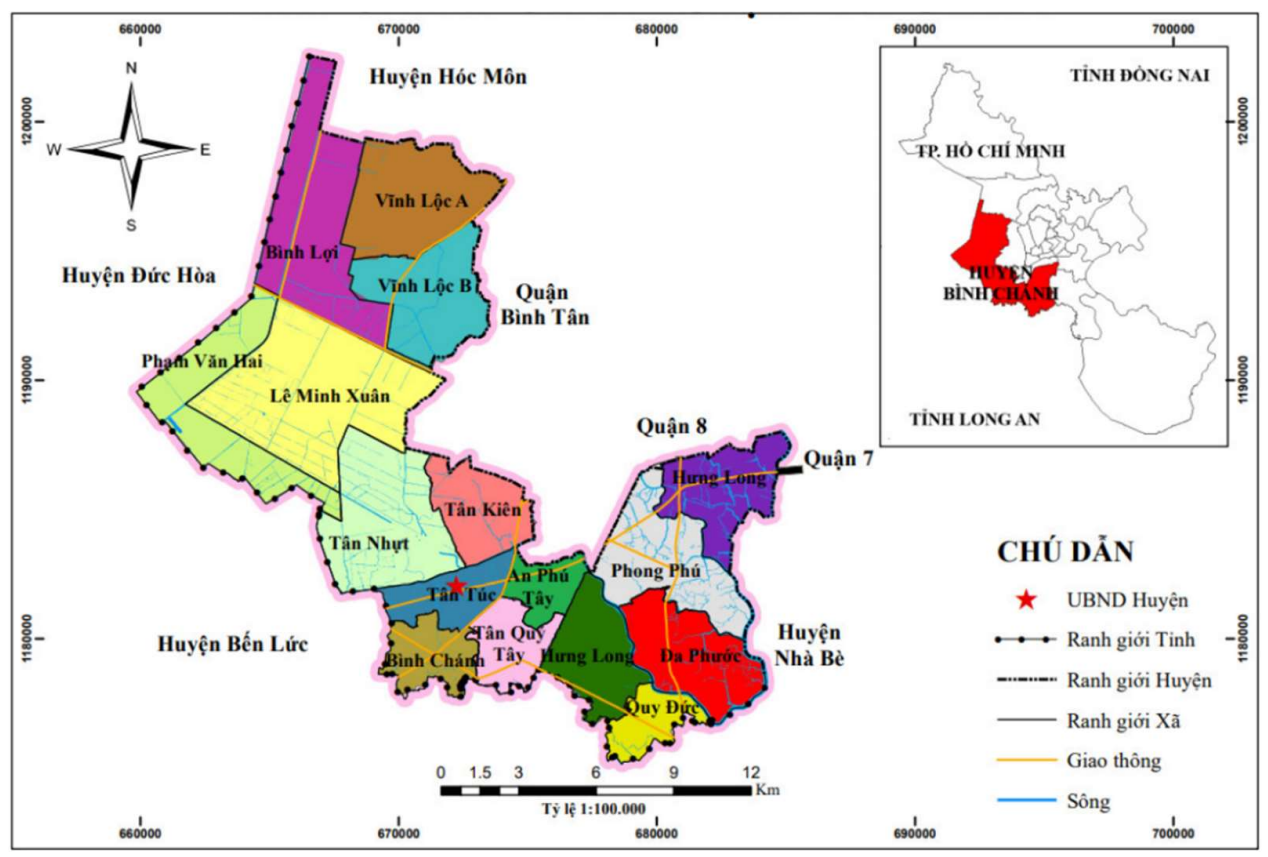

Hình 2. Bản đồ ranh giới huyện Bình Chánh.

\subsection{Phưong pháp nghiên cứu}

\subsubsection{Phương pháp thu thập, kế thừa và xử lý số liệu}

Nghiên cứu kết hợp phương pháp thu thập số liệu định tính và định lượng. Tháng 4 năm 2021, nhóm nghiên cứu đã tiến hành phỏng vấn 30 hộ dân trên địa bàn huyện Bình Chánh, TP.HCM để thu thập số liệu liên quan đến nghiên cứu. Bên cạnh đó, nghiên cứu sử dụng phương pháp xây dựng bộ tiêu chí để đánh giá mức độ quan trọng của bộ tiêu chí về khả năng áp dụng giải pháp SUDS của 10 chuyên gia và chính quyền địa phương.

Nghiên cứu thu thập và tổng hợp tài liệu, số liệu từ các đề tài nghiên cứu đã được công bố trong và ngoài nước có liên quan đến quá trình đô thị hóa, các công trình SUDS, mô hình EPA-SWMM. Kế thừa số liệu từ đề tài nghiên cứu khoa học cấp Đại học Quốc Gia Thành Phố Hồ Chí Minh mã số C2021-24-01 "Đánh giá cơ hội và thách thức phát triển hệ thống thoát nước bền vững giảm nhẹ rủi ro ngập lụt tại TP. Hồ Chí Minh”, dự án và quy hoạch hệ thống thoát nước, chống ngập đã được thực hiện trên địa bàn TP.HCM. Nghiên cứu sử dụng các báo cáo, thống kê về hiện trạng sử dụng đất, dân số, kinh tế-xã hội, hệ thống thoát nước, hiện trạng ngập lụt tại khu vực nghiên cứu theo báo cáo cuối năm 2020 của Ủy ban nhân dân huyện Bình Chánh để đánh giá hiện trạng và xây dựng mô hình EPA-SWMM. Các bản đồ, số liệu có liên quan như: Bản đồ địa giới hành chính, lượng mưa, mực nước, cao độ địa hình,... của huyện Bình Chánh năm 2018 và năm 2019. Từ đó, tổng hợp và phân tích các nội dung, phương pháp đã đề ra nhằm hoàn thiện mục tiêu nghiên cứu và đưa ra kết quả tối ưu nhất.

\subsubsection{Phương pháp mô hình toán EPA-SWMM}

Mô hình SWMM mô phỏng quan hệ giữa mưa và dòng chảy tràn, SWMM sử dụng mô hình hồ chứa phi tuyến để ước tính dòng chảy mặt (Surface Runoff) do lượng mưa tạo ra trên mỗi tiểu lưu vực. Mỗi tiểu lưu vực được mô hình hóa dưới dạng hình chữ nhật được phân 
chia theo địa hình và hạ tầng hiện hữu với các loại bề mặt đất có thể chia thành hai loại chính: Bề mặt thấm và không thấm có độ dốc lưu vực $\mathrm{S}$ và chiều rộng $\mathrm{W}$ chảy hướng ra một cửa xả duy nhất.

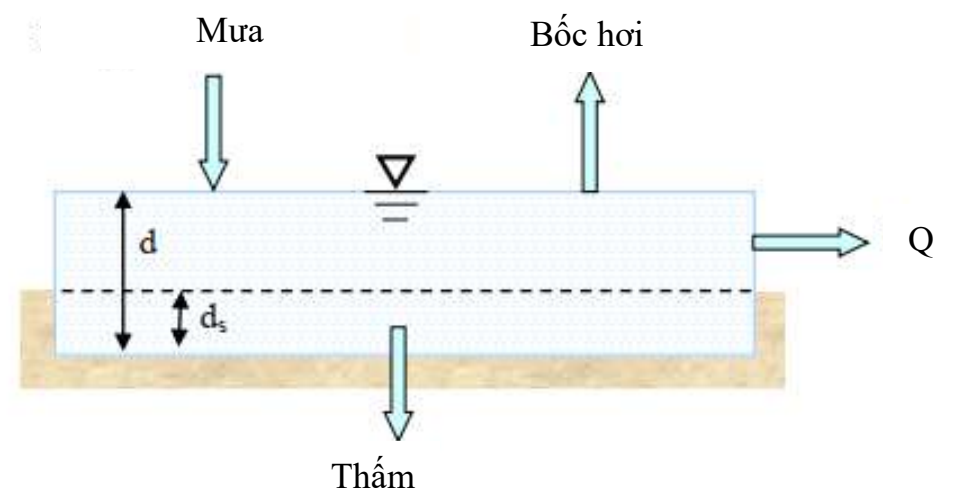

Hình 3. Mô hình mô tả dòng chảy mặt.

Tiểu lưu vực chứa dòng chảy vào từ lượng nước rơi (mưa và tuyết tan) và dòng chảy ra bao gồm: thấm, bay hơi và chảy tràn. Lưu lượng dòng chảy tràn $\mathrm{Q}$ được $\sinh$ ra khi độ sâu nước trong mỗi hồ chứa vượt quá mức lưu trữ $\mathrm{d}_{\mathrm{s}}$, trong đó phương trình hệ số nhám Manning được sử dụng để biểu thị tốc độ dòng chảy theo thể tích $\mathrm{Q}\left(\mathrm{m}^{3} / \mathrm{s}\right)$ như:

$$
\mathrm{Q}=\frac{1}{\mathrm{n}} \mathrm{W}\left(\mathrm{d}-\mathrm{d}_{\mathrm{s}}\right)^{5 / 3} \mathrm{~S}^{\frac{1}{2}}
$$

Trong đó $\mathrm{Q}$ là lưu lượng dòng chảy mặt sinh ra trên mỗi tiểu lưu vực $\left(\mathrm{m}^{3} / \mathrm{s}\right) ; \mathrm{n}$ là hệ số nhám Manning; $\mathrm{W}$ là chiều rộng tiểu lưu vực $(\mathrm{m})$; $\mathrm{d}$ là độ sâu nước trên lưu vực $(\mathrm{m}) ; \mathrm{d}_{\mathrm{s}}$ là độ sâu nước có thể trữ trong lưu vực $(\mathrm{m})$; $\mathrm{S}$ là độ dốc lưu vực $(\mathrm{m} / \mathrm{m})$.

Hệ thống thoát nước được tính toán dựa trên dữ liệu mô hình EPA-SWMM mô phỏng hệ thống thoát nước khu vực phía Tây và Nam TP.HCM, bao gồm khu vực huyện Bình Chánh. Độ dốc địa hình của từng tiểu lưu vực được xác định trực tiếp trên bản đồ số hóa của lưu vực. Tỉ lệ phần trăm không thấm so với diện tích được ước tính theo cơ cấu sử dụng đất lâu dài $50-75 \%$. Toàn bộ lưu vực được sơ đồ hóa thành 380 nút, 395 tuyến cống thoát nước với biên triều được gán ở 11 cửa xả. Sơ đồ hiện trạng được trình bày như Hình 4.

Số liệu khí tượng bao gồm: Số liệu lượng mưa, bốc hơi, độ ẩm, nhiệt độ,... Tuy nhiên, số lượng về bốc hơi, độ ẩm, nhiệt độ,... ít ảnh hưởng đến hiện tượng ngập lụt đô thị nên nghiên cứu chỉ quan tâm đến số liệu mưa. Nghiên cứu sử dụng số liệu mưa thời đoạn 15 phút tại trạm Tân Sơn Hòa để tính toán, mô phỏng tình hình ngập của khu vực nghiên cứu theo dữ liệu trận mưa lịch sử ngày $25-26 / 11 / 2018$ trong 24 giờ với tổng lượng mưa lên tới $382,5 \mathrm{~mm}$ (Hình 5a-5b).
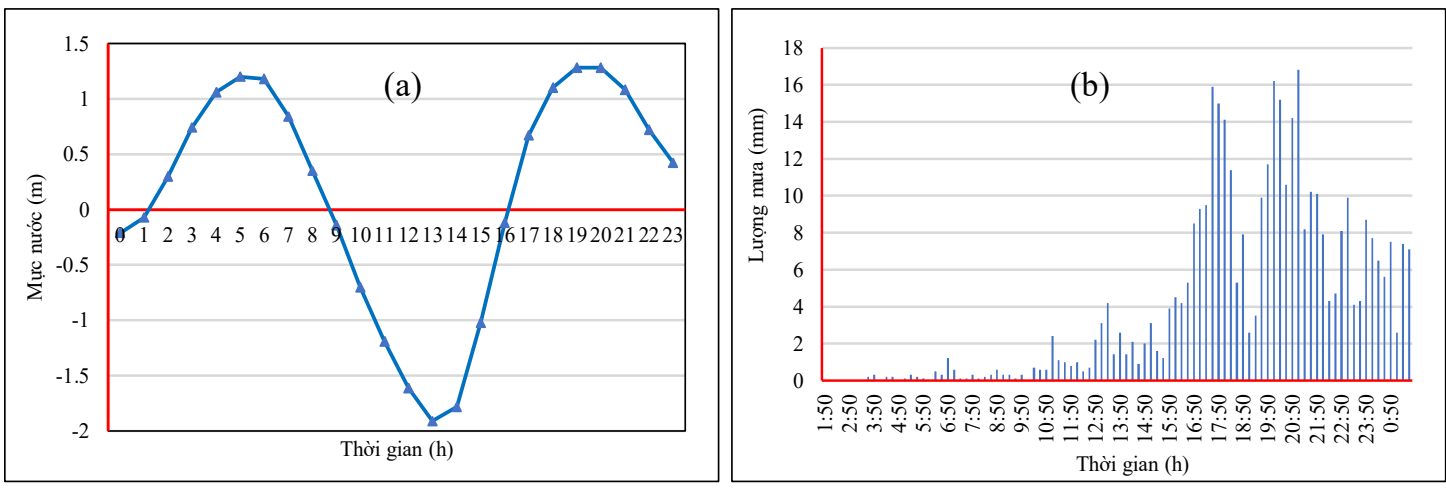

Hình 5. (a) Biểu đồ mực nước triều tính toán (Ngày 25-26/11/2018, trạm Phú An); (b) Biểu đồ mưa tính toán (Ngày 25-26/11/2018, trạm Tân Sơn Hòa). 


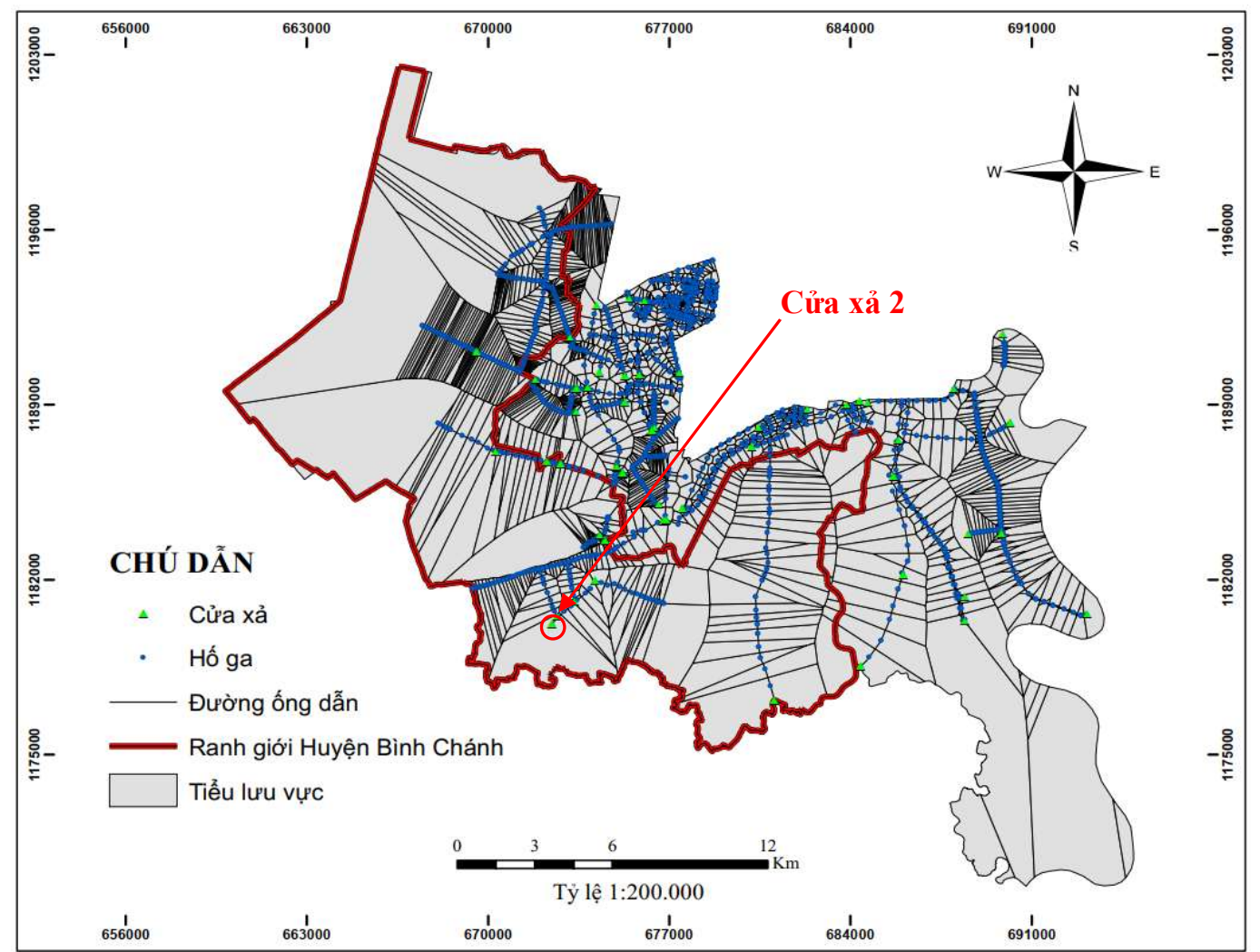

Hình 4. Sơ đồ mô phỏng mạng lưới thoát nước của khu vực nghiên cứu.

Mức độ phù hợp của mô hình và dữ liệu quan sát được đánh giá dựa trên các hệ số NSE (Nash-Sutcliffe) [19], và hệ số tương quan $\mathrm{R}^{2}$.

Nghiên cứu đề xuất 02 kịch bản để tiết giảm cường độ dòng chảy, đảm bảo hệ thống thoát nước hiện hữu có thể tiêu thoát nước:

- KB1: Kịch bản tăng khả năng lưu trữ tạm thời để tái sử dụng nước mưa;

- KB2: Kịch bản làm giảm lưu lượng đỉnh của dòng chảy.

SUDS được thực hiện bằng cách sử dụng công nghệ tác động làm chậm dòng chảy LID được mô phỏng bằng mô hình EPA-SWMM để đánh giá hiệu quả hoạt động của giải pháp thu nước mưa: Thùng chứa nước mưa; và giải pháp cải tạo mặt phủ đô thị: Mái nhà xanh, vườn mưa và vỉa hè thấm.

Nghiên cứu mô phỏng các giải pháp SUDS cho các tiểu lưu vực bị ngập úng theo kết quả đánh giá khả năng làm việc của hệ thống thoát nước trong điều kiện thời tiết bất lợi (trận mưa cực đoan ngày 25-26/11/2018 lớn nhất trong lịch sử). Số lượng các giải pháp SUDS được áp dụng trên mỗi tiểu lưu vực được xây dựng dựa trên đánh giá mức độ phù hợp về khả năng áp dụng các giải pháp SUDS tại khu vực nghiên cứu của các bên liên quan, bao gồm đánh giá mức độ phù hợp của chính quyền địa phương, người dân và chuyên gia. Bố trí giải pháp thu nước mưa với diện tích áp dụng là $0,13 \%$ và diện tích không thấm là $10 \%$ cho mỗi tiểu lưu vực. Bố trí giải pháp cải tạo mặt phủ đô thị với diện tích áp dụng cho các giải pháp là: Mái nhà xanh với diện tích áp dụng là $10 \%$ và diện tích không thấm là $35 \%$; Vườn mưa với diện tích áp dụng là $15 \%$ và diện tích không thấm là $25 \%$; Vỉa hè thấm với diện tích áp dụng là $8 \%$ và diện tích không thấm là $25 \%$ cho mỗi tiểu lưu vực.

Mỗi đề xuất nhằm cung cấp các giải pháp khác nhau trong việc quản lý lượng nước mưa hình thành nên dòng chảy mặt. Tùy thuộc vào đặc điểm của từng khu vực cũng như khả năng kinh tế của địa phương để đề xuất áp dụng các giải pháp phù hợp với nhu cầu thực tế. Việc áp dụng các giải pháp này được thực hiện đơn lẻ (Kịch bản tăng khả năng lưu trữ tạm thời để tái sử dụng nước mưa: Thu nước mưa) hoặc kết hợp với nhau (Kịch bản làm giảm lưu lượng 
đỉnh của dòng chảy: Mái nhà xanh, vỉa hè thấm và vườn mưa) nhằm đạt kết quả cao nhất trong việc áp dụng các giải pháp SUDS.

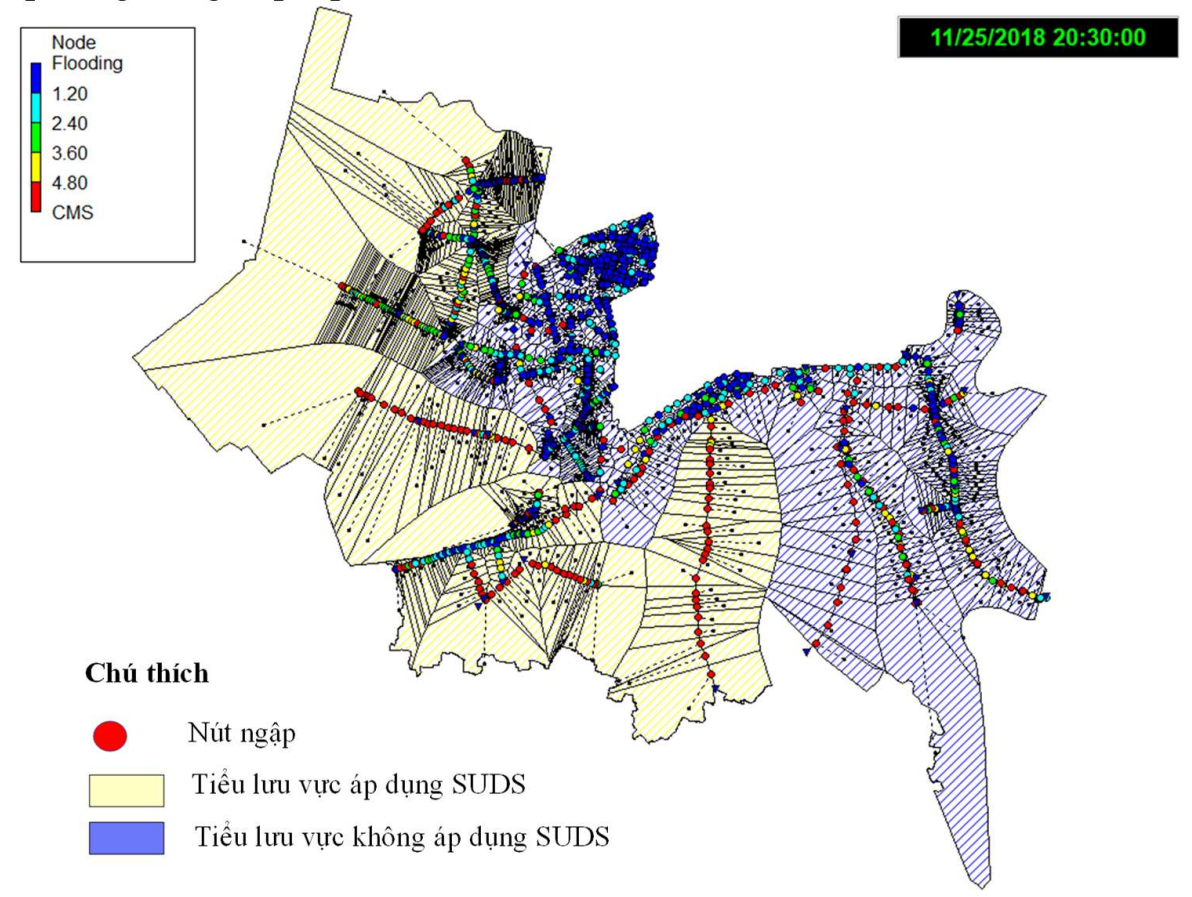

Hình 6. Bản đồ mô phỏng các tiểu lưu vực áp dụng SUDS.

\subsubsection{Phương pháp điều tra xã hội học}

Khảo sát thực tế để thu thập thông tin về hiện trạng ngập, hiện trạng hệ thống thoát nước và hiện trạng sử dụng đất tại khu vực nghiên cứu nhằm phục vụ cho công tác xây dựng và kiểm định mô hình EPA-SWMM.

Thu thập và phỏng vấn ý kiến chuyên gia và chính quyền địa phương nhằm phục vụ công tác xây dựng bộ tiêu chí để lựa chọn giải pháp SUDS phù hợp với tình hình thực tế tại khu vực nghiên cứu. Nghiên cứu phân tích số liệu thứ cấp kế thừa từ những nghiên cứu trước để xây dựng bộ tiêu chí lựa chọn giải pháp SUDS được xem xét và liệt kê. Sau khi các tiêu chí được thiết lập sẽ tiến hành phỏng vấn 10 chuyên gia và chính quyền địa phương trong các lĩnh vực về quy hoạch đô thị, môi trường, cấp thoát nước, thủy lực,... thông qua hình thức phỏng vấn sâu và khảo sát điện tử để xác định, thống nhất những tiêu chí được lựa chọn. Bên cạnh đó, bộ câu hỏi còn xây dựng dựa trên khả năng áp dụng các giải pháp SUDS đối với khu vực đang đô thị hóa, huyện Bình Chánh. Các giải pháp được chuyên gia và chính quyền địa phương đánh giá dựa trên mức độ phù hợp của các giải pháp với tình hình thực tế tại địa phương nhằm đảm bảo thực hiện đầy đủ các tiêu chí SUDS bền vững về mặt kinh tế, xã hội và môi trường.

Thu thập ý kiến của người dân với tổng số phiếu là 30 phiếu với hình thức phỏng vấn trực tiếp. Địa điểm để tiến hành phỏng vấn được lựa chọn dựa trên báo cáo ngập hằng năm của Trung tâm Chống ngập Thành phố Hồ Chí Minh (FCC), báo cáo năm của Phòng Quản lý Đô thị Huyện Bình Chánh và thông tin được đưa trên các trang báo điện tử của Huyện Bình Chánh. Ở mỗi khu vực xảy ra tình trạng ngập lụt, 1-2 hộ dân đại diện được lựa chọn lấy ý kiến khảo sát. Mục đích của cuộc khảo sát này là đánh giá mức độ ưa chuộng của cộng đồng đối với SUDS: Thu nước mưa, mái nhà xanh, vườn mưa và vỉa hè thấm. Vì vậy, việc triển khai áp dụng các giải pháp rất cần sự đồng thuận từ phía các hộ dân địa phương. Tuy nhiên, đây là nghiên cứu định tính, nên việc thu thập thông tin chỉ ngừng khi lượng thông tin bão hòa để có thể trả lời các mục tiêu và các câu hỏi nghiên cứu [20]. 


\subsubsection{Phương pháp xây dựng bộ tiêu chí}

Nghiên cứu sử dụng phương pháp xây dựng bộ tiêu chí để đo lường tính bền vững của SUDS và khả năng áp dụng SUDS tại khu vực nghiên cứu. Phương pháp này liên quan đến nhiều đối tượng trong quá trình lựa chọn các khía cạnh bền vững về mặt kinh tế, xã hội và môi trường. Các tiêu chí và chỉ số bền vững của SUDS được xác định dựa trên kết quả nghiên cứu vấn đề quản lý UDS ở Algeria [21], các chỉ thị gần đây của chính phủ về phát triển bền vững $(13 / \mathrm{CT}-\mathrm{TTg}, 20 / 5 / 2019)$ và các tài liệu nghiên cứu về tính bền vững làm cơ sở nghiên cứu xây dựng bộ tiêu chí sơ bộ được trình bày trong chỉ thị.

\section{Kết quả và thảo luận}

\subsection{Kết quả hiệu chỉnh, kiểm định mô hình}

\subsubsection{Kết quả hiệu chỉnh mô hình với trận mưa tháng 11 năm 2018}

Dùng phương án hiện trạng để kiểm nghiệm mô hình bằng cách so sánh những điểm ngập có được từ việc mô phỏng bằng mô hình với điểm ngập từ khảo sát thực tế. Kết quả mô phỏng so sánh với thực tế được gọi là phương án hiện trạng. So sánh số tuyến đường xuất hiện ngập từ khảo sát thực đo trận mưa ngày 25/11/2018 (Trung tâm điều hành chương trình chống ngập nước TP.HCM, 2018) với kết quả từ việc chạy mô hình EPA-SWMM là 11 tuyến ngập thực tế và số tuyến ngập có được do chạy mô hình là 15 tuyến ngập, như vậy tỷ lệ mô phỏng thành công của mô hình khoảng $73,33 \%$. Với hệ số NSE giữa thực đo và mô phỏng của 15 tuyến ngập đạt 0,92 và hệ số tương quan $\mathrm{R}^{2}$ đạt 0,89 . Với kết quả hiệu chỉnh hiện trạng, cho thấy mô hình có khả năng tái hiện tình trạng ngập ở khu vực huyện Bình Chánh. (Hình 7a).
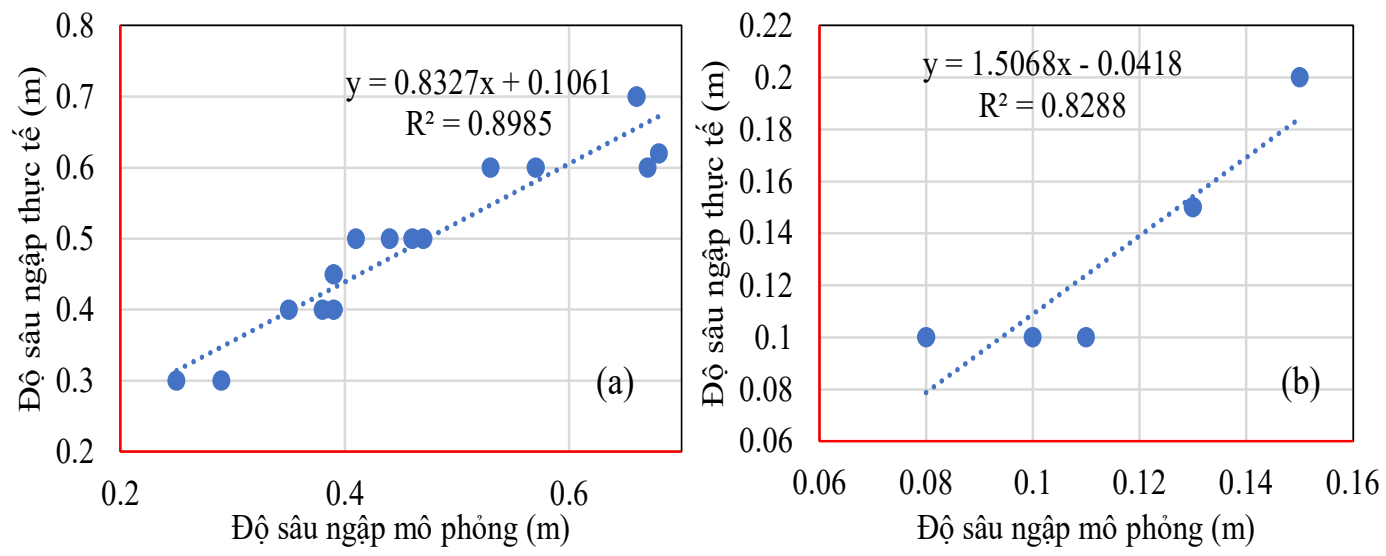

Hình 7. (a) Kết quả so sánh giữa giá trị thực đo và mô phỏng hiệu chỉnh mô hình trận mưa ngày 25/11/2018; (b) Kết quả so sánh giữa giá trị thực đo và mô phỏng kiểm định mô hình trận mưa ngày $22 / 5 / 2019$.

3.1.2. Kết quả kiểm định mô hình với trận mưa tháng 5 năm 2019

Kết quả kiểm định các thông số mô hình EPA-SWMM thông qua tính toán với trận mưa ngày 22/5/2019 trong 3h thời đoạn 15 phút trạm Bình Chánh, tổng lượng mưa là 65,4 mm, kết quả mô phỏng các tuyến ngập giữa tính toán và thực đo. So sánh số tuyến đường xuất hiện ngập từ khảo sát thực đo (trung tâm quản lý hạ tầng kỹ thuật, sở Xây Dựng thành phố TP.HCM, 2020) được trình bày trong Hình $7 b$. Hệ số NSE giữa thực đo và mô phỏng của 5 tuyến ngập đạt 0,89 và hệ số tương quan $\mathrm{R}^{2}$ đạt 0,83 .

Dựa vào kết quả kiểm định độ sâu ngập tại cái tuyến đường cho thấy, đường biểu diễn độ sâu ngập giữa thực đo và mô phỏng là tương đồng. Mô hình đủ điều kiện để mô phỏng cho diễn biến ngập úng tại khu vực huyện Bình Chánh. 


\section{2. Đánh giá khả năng áp dụng SUDS}

\subsubsection{Kết quả mô phỏng SUDS}

Mô phỏng kịch bản: Tăng khả năng lưu trữ tạm thời để tái sử dụng nước mưa (KB1) và làm giảm lưu lượng đỉnh của dòng chảy $(\mathrm{KB} 2)$. Kết quả chạy mô hình trước và sau khi đã áp dụng các giải pháp SUDS trong điều kiện lượng mưa cực đoan trong 24h ngày 25-26/11/2018 tại trạm Tân Sơn Hòa và mực nước triều điển hình cùng ngày tại trạm Phú $A n$, cho kết quả như sau:

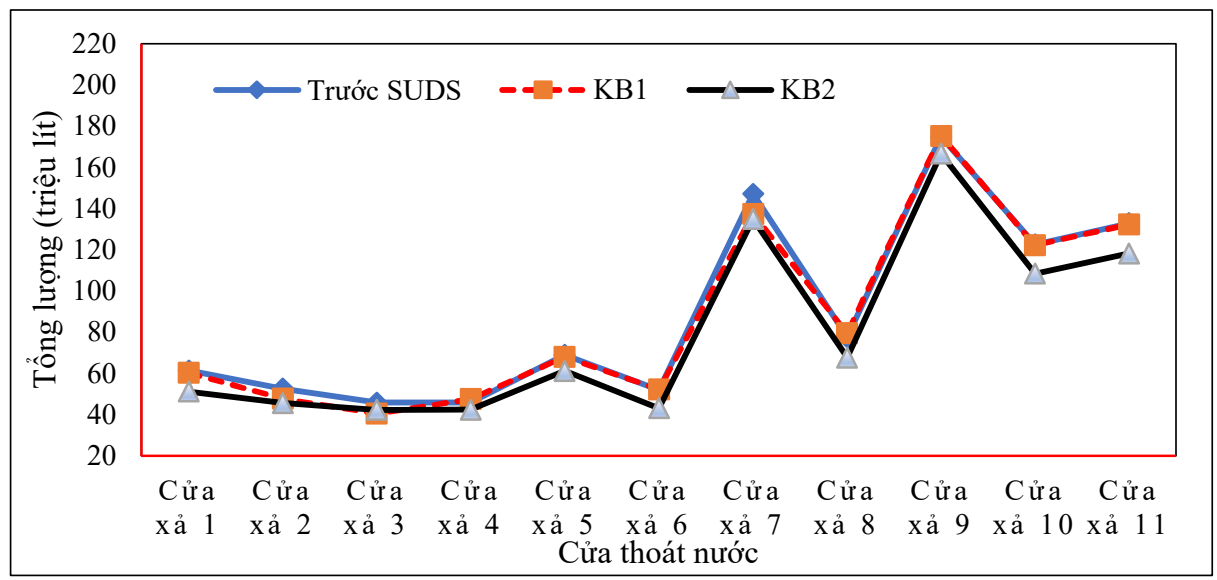

Hình 8. Biểu đồ tổng lượng tại các cửa thoát nước trước và sau khi áp dụng SUDS.

Sau khi áp dụng các giải pháp SUDS theo 2 kịch bản, tổng lượng thoát nước tại các của xả có độ giảm so với trước khi áp dụng SUDS, giảm 18,65 triệu lít với KB1 (Kịch bản tăng khả năng lưu trữ tạm thời để tái sử dụng nước mưa) và giảm 100,27 triệu lít với KB2 (Kịch bản làm giảm lưu lượng đỉnh của dòng chảy) (Hình 8 ).

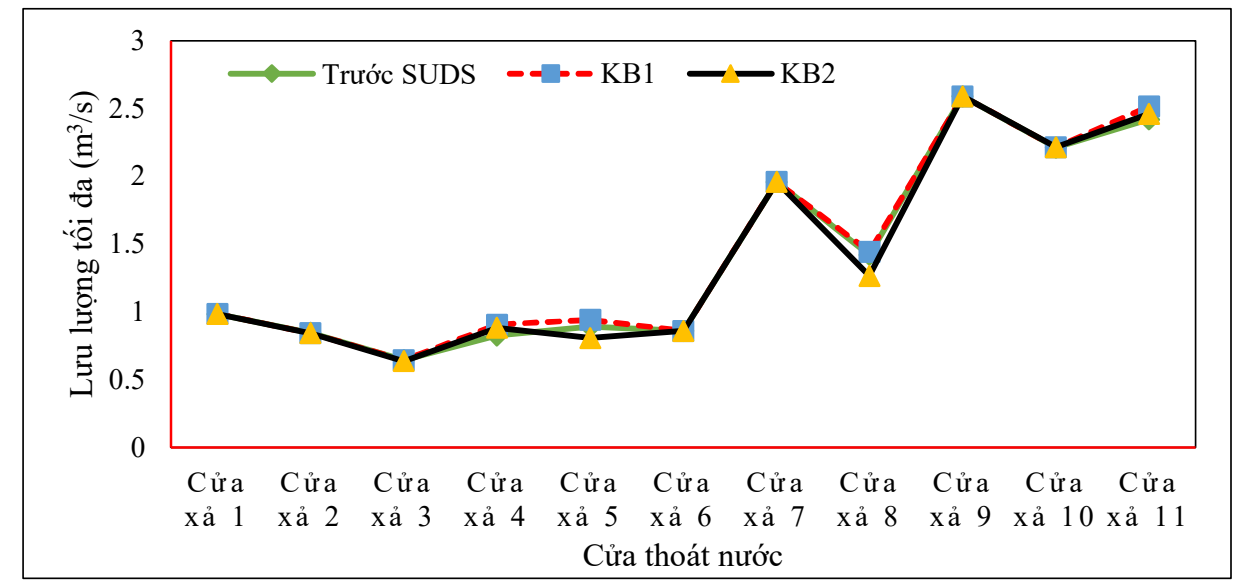

Hình 9. Biểu đồ lưu lượng tối đa tại các cửa thoát nước trước và sau khi áp dụng SUDS.

Lưu lượng đỉnh tại 11 cửa thoát nước của khu vực huyện Bình Chánh xuất hiện cao nhất tại cửa xả 9 với lưu lượng tối đa là $2,59 \mathrm{~m}^{3} / \mathrm{s}$. Kết quả so sánh đường quá trình lưu lượng tối đa tại các cửa xả cho thấy, KB2 với các giải pháp làm giảm lưu lượng đỉnh của dòng chảy mang lại hiệu quả giảm ngập đáng kể với tổng lưu lượng đỉnh tại các cửa xả giảm $0,15 \mathrm{~m}^{3} / \mathrm{s}$, giảm nhiều nhất tại cửa xả 5 , với tổng lưu lượng đỉnh giảm $0,08 \mathrm{~m}^{3} / \mathrm{s}$. KB1 với giải pháp lưu trữ tạm thời để tái sử dụng nước mưa tuy mang lại hiệu quả giảm ngập đáng kể với tổng lượng ngập giảm 18,65 triệu lít, nhưng lưu lượng đỉnh tại các cửa thoát nước không mang lại hiệu quả cao (Hình 9). 
Từ kết quả Hình 10 về đường quá trình lưu lượng thoát nước tại cửa xả 2 (Hình 4 vị trí cửa xả) sau khi áp dụng các kịch bản thoát nước giảm ngập cho thấy, 2 kịch bản đều mang lại hiệu quả giảm ngập đáng kể: Giảm $5,53 \mathrm{~m}^{3} / \mathrm{s}(9,4 \%)$ so với KB1 (Kịch bản tăng khả năng lưu trữ tạm thời để tái sử dụng nước mưa) vì khi áp dụng các giải pháp SUDS cho các lưu vực nằm trên tuyến thoát nước thì một phần lượng nước được giữ và trữ lại trong các thùng chứa nước; và giảm $7,99 \mathrm{~m}^{3} / \mathrm{s}(13,58 \%)$ so với $\mathrm{KB} 2$ (Kịch bản làm giảm lưu lượng đỉnh của dòng chảy) vì lượng nước được thấm vào đất tại các vỉa hè thấm, vườn mưa và một phần được tạm giữ và chảy chậm ở khu vực mái nhà xanh.

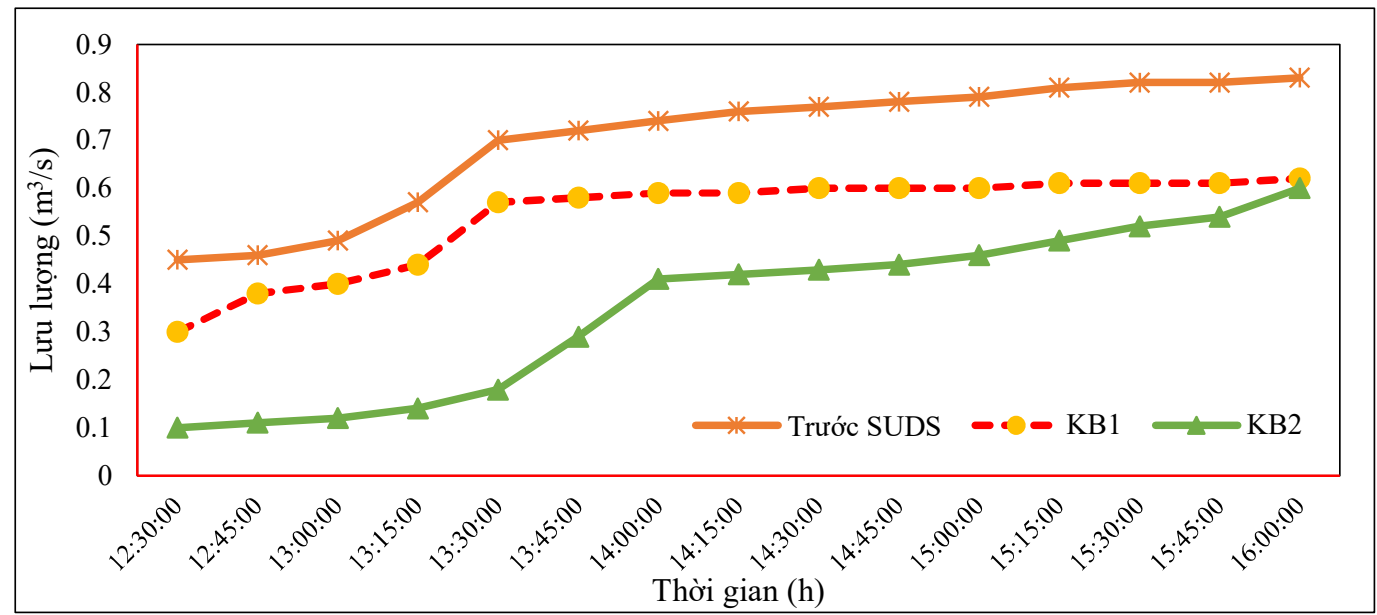

Hình 10. Biểu đồ lưu lượng tại cửa xả 2 trước và sau khi áp dụng SUDS.

Từ kết quả mô phỏng các kịch bản cho thấy, các giải pháp SUDS đem lại hiệu quả giảm ngập đáng kể:

- KB1 (Kịch bản tăng khả năng lưu trữ tạm thời để tái sử dụng nước mưa): Sau khi bố trí các thùng chứa nước mưa và tiến hành chạy mô phỏng trên mô hình $\mathrm{EPA}-\mathrm{SWMM}$, kết quả cho thấy giải pháp thùng chứa nước mưa mang lại hiệu quả nhất định trong việc giảm thiểu tình trạng quá tải của cống thoát nước. Tuy nhiên, giải pháp này không mang lại hiệu quả cao với thời gian ngập và tổng lượng ngập giảm không nhiều khi lắp đặt các thùng chứa nước mưa: Thời gian ngập giảm 0,43 giờ $(2,68 \%)$ và tổng lượng ngập giảm 298 triệu lít $(0,52 \%)$, khả năng lưu trữ tăng $22,73 \mathrm{~mm}(14,64 \%)$ so với trước khi áp dụng kịch bản.

- KB2 (Kịch bản làm giảm lưu lượng đỉnh của dòng chảy): Lượng nước mưa bị thấm của kịch bản này tăng lên $19,15 \mathrm{~mm}(50,2 \%)$, thời gian ngập giảm 3,06 giờ $(22,85 \%)$ và tổng lượng ngập giảm 8.467 triệu lít $(17,24 \%)$ so với trước khi áp dụng kịch bản. Có thể thấy, các giải pháp SUDS: Mái nhà xanh, vườn mưa và vỉa hè thấm mang lại hiệu quả đáng khích lệ. (Hình 11).

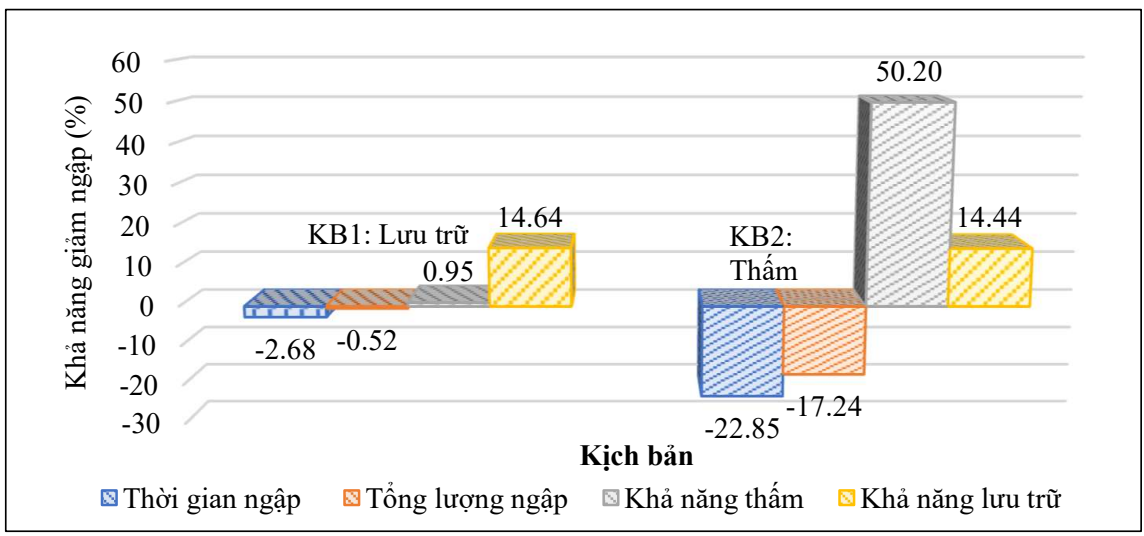

Hình 11. Kết quả so sánh hiệu quả giảm ngập của các kịch bản. 
Từ các kết quả trên cho thấy, 2 giải pháp là thu nước mưa và cải tạo mặt phủ đô thị đều mang lại hiệu quả giảm ngập, giải pháp cải tạo mặt phủ đô thị có tính hiệu quả và khả thi cao hơn so với giải phải pháp thu nước mưa. Tuy nhiên, mỗi giải pháp đều có những mặt trái của nó. Thì vậy, để có thể lựa chọn phương pháp tối ưu nhất cho khu vực đang đô thị hóa huyện Bình Chánh, nghiên cứu tiến hành đánh giá hiệu quả về mặt kinh tế, xã hội và môi trường thông qua khảo sát các bên liên quan để xây dựng bộ tiêu chí lựa chọn giải pháp SUDS và đánh giá khả năng áp dụng SUDS tại khu vực nghiên cứu.

\subsubsection{Lựa chọn SUDS dựa trên bộ tiêu chí}

a) Kết quả xây dựng bộ tiêu chí lựa chọn SUDS

Nghiên cứu xây dựng bộ tiêu chí sơ bộ dưa trên bộ chỉ thị số 13/CT-TTg ngày 20/5/2019 của chính phủ về phát triển bền vững và dựa trên kết quả nghiên cứu vấn đề về quản lý UDS ở Algeria [21]. Từ bộ tiêu chí sơ bộ, căn cứ vào tình hình thực tế tại địa phương và kết quả tham vấn ý kiến 10 chuyên gia và chính quyền địa phương, nghiên cứu tiến hành tổng hợp và lựa chọn các tiêu chí được đánh giá cao, điều chỉnh, loại bỏ và bổ sung các tiêu chí phù hợp với thực tiễn địa phương, từ đó, đề xuất bộ tiêu chí sau nhằm lựa chọn SUDS đảm bảo tính bền vững về mặt: Kinh tế, xã hội và môi trường.

Bảng 3. Các tiêu chí lựa chọn SUDS phù hợp với điều kiện tại khu vực nghiên cứu.

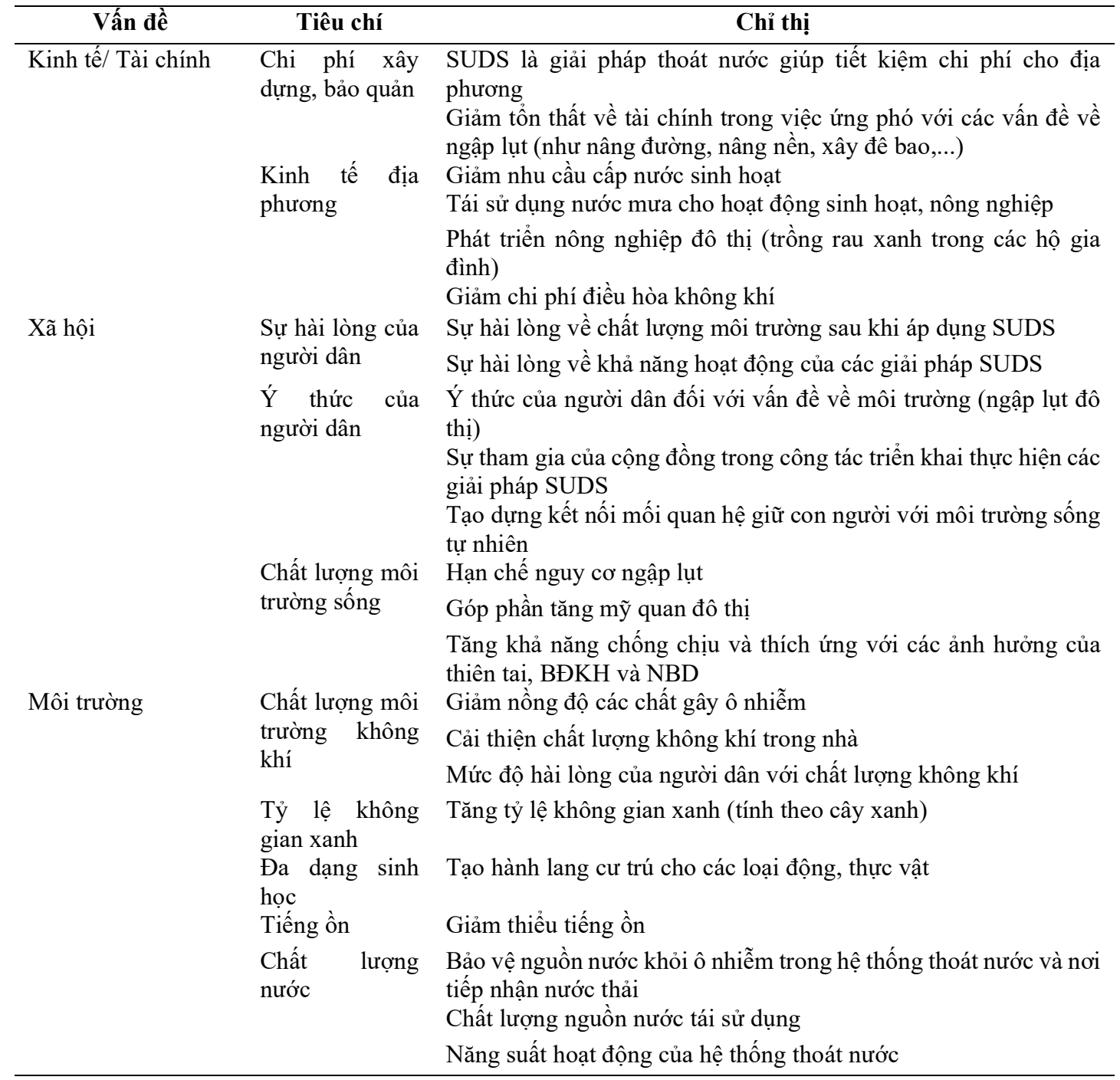




\begin{tabular}{lll}
\hline Vấn đề & \multicolumn{1}{c}{ Tiêu chí } & \multicolumn{1}{c}{ Chỉ thị } \\
\hline $\begin{array}{l}\text { Hệ thống thoát } \\
\text { nước }\end{array}$ & $\begin{array}{l}\text { Giảm tải lượng ô nhiềm thải ra } \\
\text { Hệ thống thoát nước hoạt động hiệu quả trong điều kiện mưa lớn } \\
\end{array}$ & Giảm thiểu tràn các chất ô nhiễm ra môi trường \\
\hline
\end{tabular}

Lựa chọn SUDS dựa trên bộ tiêu chí

Nghiên cứu sử dụng phương pháp điều tra xã hội học: Thu thập ý kiến của chính quyền và người dân địa phương để đánh giá khả năng áp dụng SUDS về mặt kinh tế và xã hội; Tham vấn ý kiến chuyên gia để đánh giá khả năng giảm ngập và cải thiện chất lượng môi trường tự nhiên.

Bảng 4. Đánh giá khả năng áp dụng SUDS theo bộ tiêu chí.

\begin{tabular}{|c|c|c|c|c|}
\hline \multirow{2}{*}{ Tiêu chí } & \multirow{2}{*}{$\begin{array}{c}\begin{array}{c}\text { Giải pháp tăng khả } \\
\text { năng lưu trữ tạm } \\
\text { thời }\end{array} \\
\text { Thu nước mưa }\end{array}$} & \multicolumn{3}{|c|}{ Giải pháp giảm lưu lượng đỉnh của dòng chảy } \\
\hline & & Mái nhà xanh & Vườn mưa & Vỉa hè thấm \\
\hline $\begin{array}{l}\text { Kinh tế } \\
\text { - Chi phí xây dựng/ bảo } \\
\text { quản } \\
\text { - Kinh tế địa phương }\end{array}$ & $\begin{array}{l}\text { Cao: } \\
\text { - Giảm nhu cầu cấp } \\
\text { nước } \\
\text { - Tái sử dụng nước } \\
\text { mưa vào sinh hoạt }\end{array}$ & $\begin{array}{l}\text { Thấp: } \\
\text { - Chi phí xây dựng, } \\
\text { bảo dưỡng cao }\end{array}$ & $\begin{array}{l}\text { Cao: } \\
\text { - Chi phí xây dựng } \\
\text { thấp } \\
\text { - Tăng sản lượng cây } \\
\text { trồng (rau, củ, } \\
\text { quả,...) }\end{array}$ & $\begin{array}{l}\text { Trung bình: } \\
\text { - Diện tích xây } \\
\text { dựng lớn để lưu trũ } \\
\text { nước mưa }\end{array}$ \\
\hline $\begin{array}{l}\text { Xã hội } \\
\text { - Sự hài lòng của người } \\
\text { dân } \\
\text { - Ý thức của người dân } \\
\text { - Chất lượng môi trường } \\
\text { sống }\end{array}$ & $\begin{array}{l}\text { Trung bình: } \\
\text { - Yêu cầu không gian } \\
\text { xây dựng thiết bị } \\
\text { - Bảo trì, bảo dưỡng } \\
\text { thường xuyên }\end{array}$ & $\begin{array}{l}\text { Thấp: } \\
\text { - Khó thay đổi nhìn } \\
\text { nhận từ người sử } \\
\text { dụng } \\
\text { - Cần tính thêm tải } \\
\text { trọng cho mái nhà }\end{array}$ & $\begin{array}{l}\text { Cao: } \\
\text { - Tạo cảnh quan } \\
\text { - Tăng khả năng } \\
\text { chống chịu của thiên } \\
\text { tai } \\
\text { - Sự tham gia của } \\
\text { cộng đồng }\end{array}$ & $\begin{array}{l}\text { Trung bình: } \\
\text { - Tăng mỹ quan đô } \\
\text { thị } \\
\text { - Được sự dồng } \\
\text { thuận của cộng } \\
\text { dồng }\end{array}$ \\
\hline $\begin{array}{l}\text { Môi truoơng } \\
\text { - Chất lượng môi trường } \\
\text { không khí } \\
\text { - Tỷ lệ không gian xanh } \\
\text { - Đa dạng sinh học } \\
\text { - Tiếng ồn } \\
\text { - Chất lượng nước } \\
\text { - Hệ thống thoát nước }\end{array}$ & $\begin{array}{l}\text { Thấp: } \\
\text { - Giảm áp lực lên hệ } \\
\text { thống thoát nước } \\
\text { - Đảm bảo nguồn } \\
\text { nước tái sử dụng }\end{array}$ & $\begin{array}{l}\text { Cao: } \\
\text { - Cải thiện chất } \\
\text { lượng không khí, ôn } \\
\text { định nhiệt độ } \\
\text { - Tạo không gian } \\
\text { xanh }\end{array}$ & $\begin{array}{l}\text { Cao: } \\
\text { - Cải thiện chất } \\
\text { lượng không khí } \\
\text { - Tăng tỷ lệ cây xanh } \\
\text { - Tạo hành lang cư } \\
\text { trú cho động, thực } \\
\text { vật } \\
\text { - Giảm tải lượng ô } \\
\text { nhiễm thải ra }\end{array}$ & $\begin{array}{l}\text { Cao: } \\
\text { - Giảm ô nhiễm } \\
\text { không khí } \\
\text { - Giảm áp dụng lên } \\
\text { hệ thống thoát nước } \\
\text { - Giảm tải ô nhiếm } \\
\text { chất thải }\end{array}$ \\
\hline
\end{tabular}

Nhìn chung, các giải pháp SUDS khi áp dụng tại khu vực đang đô thị hóa, huyện Bình Chánh đa phần đều đáp ứng các tiêu chí về môi trường, tuy nhiên cũng gặp phải không ít thách thức bởi sự phụ thuộc nhiều vào các bên liên quan về khả năng chi trả, bảo trì bảo dưỡng và hiệu quả giảm ngập của SUDS. Dựa trên kết quả đánh giá mức độ phù hợp của SUDS với bộ tiêu chí, cần tập trung vào giải pháp vườn mưa và vỉa hè thấm bởi nhóm giải pháp này đạt hiệu quả vượt trội khi so sánh cả về chi phí, sự đồng thuận, hiệu quả giảm ngập và đảm bảo tính bền vững về môi trường. Tuy nhiên, việc lựa chọn giải pháp nào cũng cần nghiên cứu thực tế theo khu vực bởi việc xây dựng giải pháp có thể mang lại hiệu quả cao và lợi ích chi phí cao hơn đối với các dự án đầu tư xây mới.

b) Kết quả khảo sát các bên liên quan

Trong khi kết quả từ mô hình hóa sẽ đưa ra các quan điểm về mặt kỹ thuật, còn khảo sát trực tiếp từ các bên liên quan cho thấy nhận thức và khả năng áp dụng SUDS tại địa phương. Dưới đây là kết quả khảo sát các bên liên quan: 


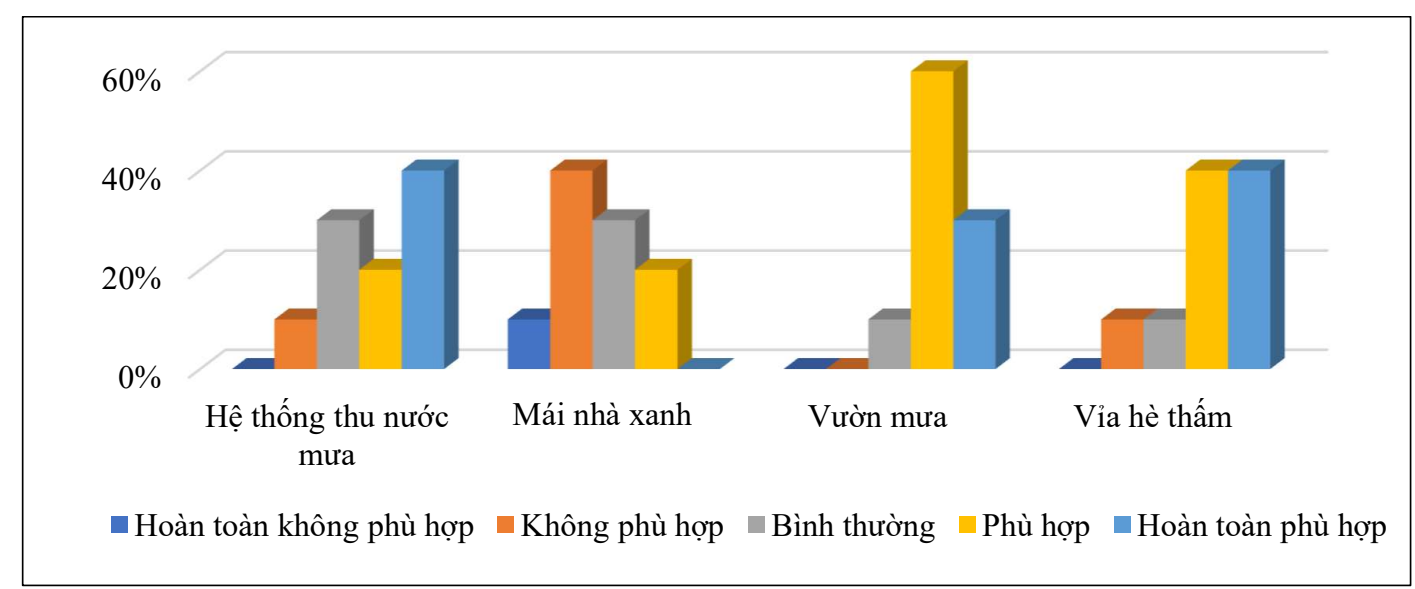

Hình 12. Kết quả khảo sát chuyên gia và chính quyền địa phương về lựa chọn SUDS.

Kết quả thu thập ý kiến chuyên gia và chính quyền địa phương cho thấy, các giải pháp vườn mưa, vỉa hè thấm là các giải pháp được đánh giá là phù hợp với đặc điểm của khu vực nghiên cứu với mức độ phù hợp là $90 \%$ đối với giải pháp vườn mưa và $80 \%$ đối với giải pháp vỉa hè thấm. Tiếp đến là các giải pháp hệ thống thu nước mưa cũng được đánh giá là phù hợp với mức độ phù hợp được đánh giá là $60 \%$. Cuối cùng là giải pháp mái nhà xanh được đánh giá là ít phù hợp nhất với mức độ phù hợp được đánh giá là $20 \%$, mức độ đánh giá không phù hợp là $50 \%$ và $30 \%$ còn lại là ý kiến trung lập (Hình 12).

Kết quả tổng hợp ý kiến khảo sát người dân địa phương cho thấy giải pháp vỉa hè thấm là giải pháp được ưa chuộng nhất với sự chấp thuận cho giải pháp này là $74 \%$ trên tổng số hộ dân được lấy ý kiến. Giải pháp vườn mưa là giải pháp thứ 2 được người dân ưa chuộng với sự đồng thuận là $63 \%$, đây là một trong những giải pháp phổ biến nhất được triển khai thực hiện ở nhiều nước trên thế giới. Thứ 3 là giải pháp hệ thống thu nước mưa với tỷ lệ đồng thuận là $44 \%$, nước mưa được thu lại từ các hồ chứa, bể chứa trong nhà. Mặc dù giải pháp mái nhà xanh có khả năng giảm lưu lượng dòng chảy, nhưng nhìn chung, loại giải pháp này ít được người dân ưa chuộng nhất với mức độ không đồng thuận là $57 \%$ trên tổng số hộ dân được lấy ý kiến. Giải pháp này dường như còn khá xa lạ nên đa số hộ dân đều không chấp nhận hoặc không có ý kiến đối với giải pháp này. Khi được hỏi cụ thể về giải pháp này, người dân đều thấy khả năng phủ một lớp thực vật trên mái nhà của họ là điều không thể thực hiện vì rất khó có thể chăm sóc và khả năng sẽ có sự xuất hiện của nhiều loại côn trùng (Hình 13).

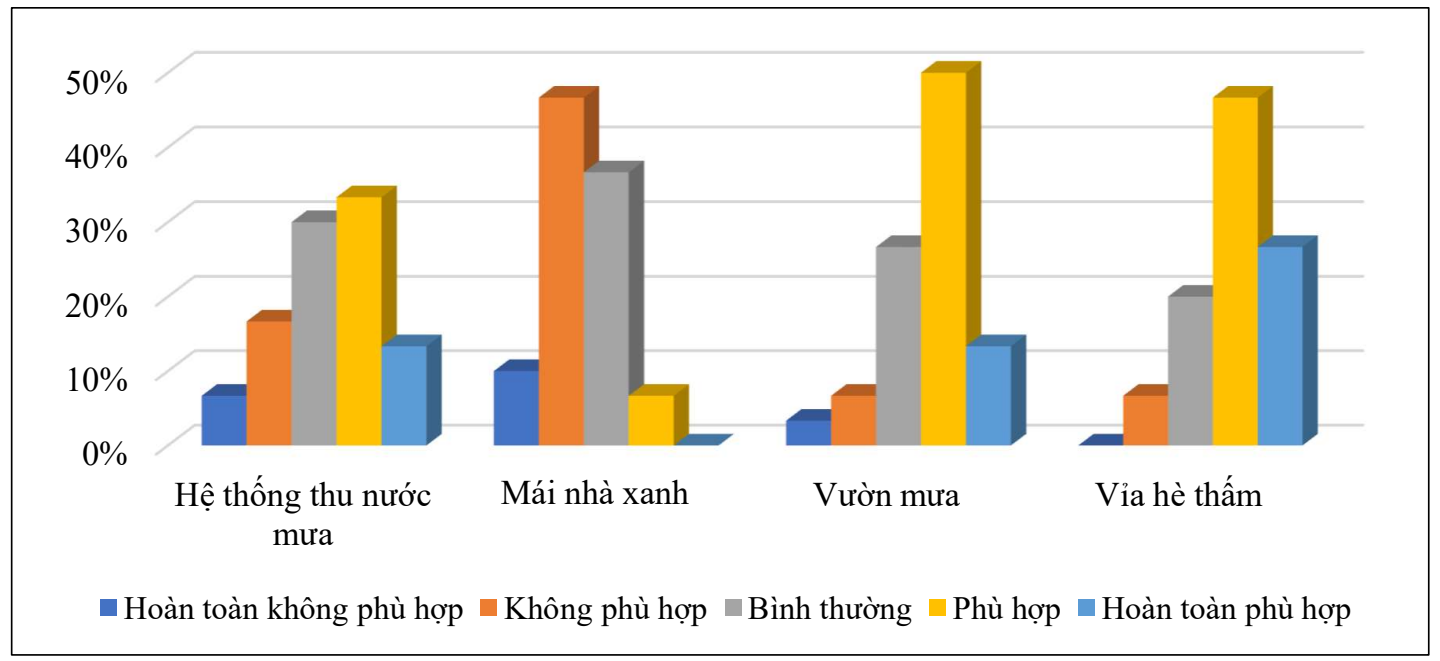

Hình 13. Kết quả khảo sát người dân về lựa chọn SUDS. 
Sau khi tổng hợp kết quả khảo sát của các bên liên quan cho thấy giải pháp vỉa hè thấm và vườn mưa được ưa chuộng và đánh giá phù hợp với khu vực nghiên cứu nhất $(77 \%)$, tiếp theo là giải pháp hệ thống thu nước mưa $(53 \%)$ và cuối cùng là giải pháp mái nhà xanh $(14 \%)$.

\section{Kết luận}

Nghiên cứu sử dụng phần mềm EPA-SWMM đã được hiệu chỉnh và kiểm định khá tốt cho mô hình thoát nước cho khu vực Bình Chánh, sau đó mô phỏng 2 kịch bản áp dụng giải pháp SUDS: Kịch bản tăng khả năng lưu trữ tạm thời để tái sử dụng nước mưa (Thu nước mưa); và kịch bản làm giảm lưu lượng đỉnh của dòng chảy (Mái nhà xanh, vườn mưa và vỉa hè thấm). Kết quả sau khi chạy mô phỏng các giải pháp SUDS theo kịch bản đề xuất được thực hiện bằng cách mô phỏng LID bằng mô hình EPA-SWMM cho thấy các giải pháp đã mang lại hiệu quả giảm ngập đáng kể: Giải pháp thu nước mưa với thời gian ngập giảm 0,43 giờ $(2,68 \%)$ và tổng lượng ngập giảm 298 triệu lít $(0,35 \%)$; và giải pháp cải tạo mặt phủ đô thị với thời gian ngập giảm 3,06 giờ $(22,85 \%)$ và tổng lượng ngập giảm 8.467 triệu lít $(17,24 \%)$. Từ kết quả phân tích trên cho thấy, giải pháp cải tạo mặt phủ đô thị có tính hiệu quả và khả thi cao hơn so với giải pháp thu nước mưa. Kết quả lựa chọn giải pháp SUDS dựa trên mức độ phù hợp với bộ tiêu chí được đề xuất, cần tập trung vào giải pháp vườn mưa và vỉa hè thấm bởi nhóm giải pháp này đạt hiệu quả vượt trội khi so sánh cả về chi phí, sự đồng thuận, hiệu quả giảm ngập và đảm bảo tính bền vững về môi trường. Qua kết quả thu thập ý kiến của 10 chuyên gia và chính quyền địa phương cho thấy, các giải pháp vườn mưa, vỉa hè thấm được đánh giá là phù hợp với đặc điểm của khu vực nghiên cứu với mức độ phù hợp là $90 \%$ đối với giải pháp vườn mưa và $80 \%$ đối với giải pháp vỉa hè thấm, tiếp đến là các giải pháp hệ thống thu nước mưa cũng được đánh giá là phù hợp với mức độ phù hợp là $60 \%$, cuối cùng là giải pháp mái nhà xanh được đánh giá là ít phù hợp nhất với mức độ phù hợp được đánh giá là $20 \%$. Kết quả thu thập ý kiến của 30 hộ dân tại địa phương cho thấy, giải pháp vỉa hè thấm là giải pháp được ưa chuộng nhất với sự chấp thuận là $74 \%$, thứ 2 là giải pháp vườn mưa với sự đồng thuận là $63 \%$, thứ 3 là giải pháp hệ thống thu nước mưa với tỷ lệ đồng thuận là $44 \%$, cuối cùng là giải pháp mái nhà xanh với mức độ không đồng thuận lên đến $57 \%$, giải pháp này dường như còn khá xa lạ nên đa số hộ dân đều không chấp nhận hoặc không có ý kiến đối với giải pháp này.

Kết quả nghiên cứu cung cấp thông tin cho việc lựa chọn giải pháp SUDS phù hợp với điều kiện thực tế tại khu vực đang đô thị hóa ở huyện Bình Chánh. Sau khi đánh giá về mặt kỹ thuật, kinh tế, xã hội và môi trường thì 2 giải pháp là vỉa hè thấm và giải pháp vườn mưa được đánh giá là phù hợp và được ưa chuộng nhất tại khu vực nghiên cứu. Các giải pháp SUDS được đề xuất ở huyện Bình Chánh giúp tăng khả năng giảm ngập trong các trận mưa lớn, nghiên cứu này có thể xem xét áp dụng ở TP.HCM và các thành phố khác có cùng khí hậu và đặc điểm địa hình.

Mô hình EPA-SWMM còn có khả năng tính toán nồng độ các chất ô nhiễm trong các trận mưa và đánh giá khả năng giảm tải các chất ô nhiễm của SUDS. Tuy nhiên, nghiên cứu còn hạn chế về thời gian thực hiện cũng như nguồn dữ liệu phân tích chưa đủ dày nên mô hình chỉ dừng lại ở việc phân tích hiện trạng ngập và mô phỏng kịch bản làm giảm lưu lượng đỉnh của dòng chảy và tăng khả năng lưu trữ tạm thời để tái sử dụng nước mưa. Do đó, để nghiên cứu tài mang tính thực tiễn, cần có nghiền cứu tiếp theo để đánh giá nồng độ các chất ô nhiễm và đề xuất giải pháp khắc phục.

Đóng góp của tác giả: Thu thập, phân tích, xử lý số liệu: N.T.M.L., N.N.H.G., H.V.H., L.V.T.; Viết bản thảo bài báo: N.T.M.L.; Xây dựng ý tưởng nghiên cứu: C.N.X.Q.; Lựa chọn phương pháp nghiên cứu: C.N.X.Q., T.D.D.; Chỉnh sửa bài báo: T.D.D., H.V.H.

Lời cảm ơn: Nghiên cứu được tài trợ bởi Đại học Quốc gia Thành Phố Hồ Chí Minh (ĐHQGHCM) trong khuôn khổ Đề tài mã số C2021-24-01. 
Lời cam đoan: Tập thể tác giả cam đoan bài báo này là công trình nghiên cứu của tập thể tác giả, chưa được công bố ở đâu, không được sao chép từ những nghiên cứu trước đây; không có sự tranh chấp lợi ích trong nhóm tác giả.

\section{Tài liệu tham khảo}

1. Landsberg, H.E. Man-Made Climatic Changes. Science 1970, 170, 1265-1274.

2. Paul, M.J.; Meyer, J.L. Streams in the Urban Landscape. Annu. Rev. Ecol. Evol. Syst. 2001, 32, 333-365.

3. Bộ Tài nguyên và Môi trường. Kịch bản biến đổi khí hậu và nước biển dân cho Việt Nam. Tài nguyên Môi trường và Bản đồ Việt Nam, 2016.

4. Hiếu, N.V.; Tú, T.T.; Hòa, H.V.; Nam, T.H. Đánh giá phương pháp tiếp cận giảm ngập phân tán tại khu vực trũng thấp ngoại vi thành phố hồ chí minh (tại khu dân cư ở Phường Bình Trưng Tây, Quận 2, Tp.HCM). Tạp chí Người Xây Dựng 2019, 01\&02-2019.

5. Carter, T.; Butler, C. Ecological impacts of replacing traditional roofs with green roofs in two urban areas. Cities Environ. 2008, 1(2), 9.

6. Mentens, J.; Raes, D.; Hermy, M. Dirk Raes and Department, Green roofs as a tool for solving the rainwater runoff problem in the urbanized 21st century? Landscape Urban Plann. 2006, 77, 217-226.

7. de Oliveira, E.W.N.; da Silva, L.P.; Mary, W. Telhados verdes para habitações de interesse social: retenção das águas pluviais e conforto térmico. Universidade do Estado do Rio de Janeiro, 2009, pp. 18.

8. Hoffmann, B. et al. Sustainable Urban Drainage Systems. Sustainable Urban Drainage Systems, 2016, pp. 20.

9. Zhang, L.; Ye, Z.; Shibata, S. Assessment of Rain Garden Effects for the Management of Urban Storm Runoff in Japan. Sustainability 2020, 12 (23), 9982.

10. Urbonas, B.; Stahre, P. Stormwater Best management Practices and Detention. Prentice Hall, Englewood Cliffs, New Jersey, 1993, pp. 450.

11. Rutinei, T.; Cristiano, P. Sustainable Urban Drainage Systems (Brazil). Tech Europe, 2012.

12. Rossman, L.A. Storm Water Management Model Reference Manual, Volume I Hydrology (Revised), 2016.

13. Rosenberg, E.A.; Keys, P.W.; Booth, D.B.; Hartley, D.; Burkey, J.; Steinemann, A.C.; Lettenmaier, D.P. Precipitation extremes and the impacts of climate change on stormwater infrastructure in Washington State. Clim. Change 2010, 102, 319-349.

14. Woicik, P.A.; Moeller, S.J.; Alia-Klein, N.; Maloney, T.; Lukasik, T.M.; Yeliosof, O.; Wang, G.J.; Volkow, N.D.; Goldstein, R. The Neuropsychology of Cocaine Addiction: Recent Cocaine Use Masks Impairment. Neuropsychopharmacology. 2009, 34(5), 1112-0.

15. Ngọc, Đ.X.; Tuyên, T.H.; Tùng, H.H. Mô phỏng thoát nước đô thị Huế trong trận mưa tháng 10 năm 2010. Tạp chí Khí tuợng Thủy Văn 2015.

16. Lộc, H.H. Social Aspects of the Application of SUDS for the case of Nhieu Loc-Thi Nghe Basin, Ho Chi Minh City, 2014.

17. Nữ, H.T.T.; Vũ, Đ.T.; Phùng, L.V.; Văn, C.T. Mô phỏng mức độ ngập và đề xuất giải pháp thoát nước chống ngập cho khu vực Văn Thánh - thành phố Hồ Chí Minh. Tạp chí Khí tượng Thủy Văn 2020, 716, 12-25.

18. Lên, N.T. Úng dụng mô hình thủy văn EPA SWMM, sóng động lực phân tích mạng lưới thoát nước cho khu đô thị mới Lê Minh Xuân, huyện Bình Chánh, TP. Hồ Chí Minh. Tạp chí Khoa học và Công nghệ 2020, 18(7), 90-95.

19. Lee, J.G.; Nietch, C.T.; Panguluri, S. SWMM Modeling Methods for Simulating Green Infrastructure at a Suburban Headwatershed: User's Guide. U.S. Environmental Protection Agency, 2017, pp. 157. 
20. Marshall, B.; Cardon, P.; Poddar, A.; Fontenot, R. Does Sample Size Matter in Qualitative Research?: A Review of Qualitative Interviews in is Research. $J$. Comput. Inf. Syst. 2013, 54(1), 11-22.

21. Benzerra, A.; Cherrared, M.; Chocat, B.; Cherqui, F.; Zekiouk, T. Decision support for sustainable urban drainage system management: A case study of Jijel, Algeria. $J$. Environ. Manage. 2012, 46-53.

\title{
Assessing the applicability of Sustainable Urban Drainage Systems in Binh Chanh district, Ho Chi Minh city
}

\author{
Nguyen Thi Mai Lan ${ }^{1}$, Tran Duc Dung ${ }^{*}$, Chau Nguyen Xuan Quang ${ }^{2}$, Ngo Ngoc Hoang \\ Giang $^{2}$, Ho Van $\mathrm{Hoa}^{2}$, Luu Van Tan ${ }^{3}$ \\ ${ }^{1}$ Center of Water Management and Climate Change, Institute for Environment and \\ Resources, Vietnam National University - Ho Chi Minh City (VNU-HCM), Ho Chi \\ Minh City, Vietnam; dungtranducvn@yahoo.com; mailan300496@gmail.com \\ ${ }^{2}$ Department of Hydrology and Water Resources, Institute of Environment and Natural \\ Resources, Vietnam National University Ho Chi Minh City (HYDROWARE-IRE- \\ VNU); cnxquang@gmail.com; nnhgiang.env@gmail.com; harryhoa@gmail.com \\ ${ }^{3}$ HCMC Infrastructure Management Center; taanslv@yahoo.com
}

\begin{abstract}
The uncontrolled urbanization and the situation of climate change are one of the causes of local inundation. This study aims to evaluate the applicability of the Sustainable urban drainage solution (SUDS) in the urbanizing area, Binh Chanh district. The Storm Water Management Model (EPA-SWMM) is used to simulate two scenarios for applying SUDS solutions: The scenario of increasing temporary storage capacity for reuse rainwater (Scenario 1) and reducing peak discharge of stormwater runoff (Scenario 2), design SUDS selection criteria combined with a survey of 30 households, 10 experts and local government to assess the applicability of SUDS. The simulation results of the scenario have brought about a significant flood reduction effect: Scenario 1 with flooding time decreased by $2,68 \%$, and the total flood volume was reduced by $0,52 \%$, and scenario 2 with flooding time decreased by $22,85 \%$, and the total flood volume was reduced by $17,24 \%$. Furthermore, based on the suitability with the proposed SUDS selection criteria with the survey of stakeholders, our results indicate that the porous pavements and rain gardens solutions were the most popular and suitable for the study area, followed by the rainwater harvesting finally the green. The study results indicate that the SUDS have a significant flood reduction effect, supporting urban flood risk management more efficiently.
\end{abstract}

Keywords: Urbanizing; Binh Chanh district; EPA-SWMM; SUDS. 